\title{
UPAYA MENINGKATKAN HASIL BELAJAR IPS EKONOMI DENGAN MENGGUNAKAN MODEL PEMBELAJARAN KOOPERATIF TIPE SNOWBALL THROWING PADA KELAS VIII MTS HIDAYATUL INSAN PALANGKA RAYA
}

\author{
Oleh \\ Raudah,* Isna Mariani** \\ Email:isnamariyani@yahoo.com
}

\begin{abstract}
This study aims to determine learning activities and learning outcomes. This type of research is Class Action Research (CAR). The subjects of this study were class VIII students of Usman bin Affan, MTs Hidayatul, Palangka Raya Individuals totaling 17 students. This data collection technique is observation and testing. Data analysis techniques are based on the results of the cycle during the learning process. The results of the study concluded that: (1) learning activities of students in Economics Social Studies learning by applying the cooperative learning model Snowball Throwing type in class VIII Usman bin Affan MTs Hidayatul Insanity Palangka Raya was more active, (2) there was an increase in Social Economics learning outcomes after applying the model cooperative learning Type Snowball Throwing on class VIII students of Usman bin Affan MTs Hidayatul Insan Palangka Raya.
\end{abstract}

(C) Muhammadiyah University of Palangkaraya

Keywords: Cooperative Learning Model, Snowball Throwing type

\begin{abstract}
ABSTRAK
Penelitian ini bertujuan untuk mengetahui aktivitas belajar dan hasil belajar. Jenis penelitian ini adalah Penelitian Tindakan Kelas (PTK). Subjek penelitian ini adalah peserta didik kelas VIII Usman bin Affan MTs Hidayatul Insan Palangka Raya berjumlah 17 orang peserta didik. Teknik pengumpulan data ini adalah observasi dan tes. Teknik analisis data didasarkan pada hasil siklus pada saat proses pembelajaran. Hasil penelitian disimpulkan bahwa: (1) aktivitas belajar peserta didik dalam pembelajaran IPS Ekonomi dengan menerapkan model pembelajaran kooperatif tipe Snowball Throwing pada kelas VIII Usman bin Affan MTs Hidayatul Insan Palangka Raya lebih aktif, (2) ada peningkatan hasil belajar IPS Ekonomi setelah menerapkan model pembelajaran kooperatif Tipe Snowball Throwing pada peserta didik kelas VIII Usman bin Affan MTs Hidayatul Insan Palangka Raya.
\end{abstract}

(C) Universitas Muhammadiyah Palangkaraya

Kata Kunci: Model Pembelajaran Kooperatif, tipe Snowball Throwing 


\section{PENDAHULUAN}

Suatu cara untuk meningkatkan kualitas sumber daya manusia adalah dengan pendidikan. Pendidikan adalah usaha sadar dan terencana untuk mewujudkan suasana belajar dan proses pembelajaran agar peserta didik secara aktif mengem- bangkan potensi dirinya sehingga proses pengubahan sikapdan tingkah laku seseorang yang merupakan tujuan pendidikan dapat tercapai secara efektif dan efisien.

$\begin{array}{ccr}\text { Adapun } & \text { tujuan } & \text { daripada } \\ \text { pendidikan } & \text { nasional } & \text { adalah }\end{array}$
menyukseskan proses belajar mengajar disekolah yang tertuang di dalam Undang-Undang Republik Indonesia No. 20 Tahun 2003 Pasal 3 tentang Sisdiknas yaitu Pendidikan Nasional berfungsi mengembangkan kemampuan dan memben- tukwatak serta peradaban bangsa, bertujuan untuk perkembangannya potensi peserta didik agar menjadi manusia yang beriman dan bertaqwa kepada Tu- han Yang Maha Esa, berakhlak mulia, berilmu, cakap, kreatif, mandiri dan menjadi warga negara yang demokratis serta bertanggung jawab. (UU RI NO. 20 Tentang Sistem Pendidikan, 2003:8).

Secara sederhana pendidikan dapat diartikan sebagai usaha sadar manusia untuk menumbuhkan dan mengembangkan potensi diri yang dimiliki sesuai dengan nilai-nilai yang ada dimasyarakat. Peningkatan mutu pendidikan merupakan program yang sangat penting dalam dunia pendidikan sehingga diperlukan sistem pendidikan di dalamnya termasuk proses pembelajaran.
Proses pembelajaran di sini meliputi interaksi peserta didik dengan pendidik dan sumber belajar pada suatu lingkungan belajar. Dalam kegiatan pembelajaran dilakukan oleh dua orang pelaku yaitu guru dan peserta didik. Perilaku guru adalah mengajar dan perilaku peserta didik adalah belajar. Guru dan peserta didik pada saat proses belajar mengajar memegang peranan yang sangat penting dalam menyukseskan hasil belajar yang memuaskan. Keberhasilan proses pembelajaran tidak terlepas dari kemampuan guru mengembangkan model-model pembelajaran yang berorientasi pada peningkatan intensitas keterlibatan peserta didik secara aktif di dalam proses pembelajaran. Pengembangan model pembelajaran yang tepat bertujuan untuk menciptakan kondisi pembelajaran yang memungkinkan peserta didik dapat belajar secara aktif dan menyenangkan sehingga peserta didik dapat meraih hasil belajar dan prestasi belajar yang optimal.

Perubahan-perubahan tingkah laku pada peserta didik karena belajar merupakan hasil belajar. banyak ahli yang mengemukakan pendapatnya tentang hasil belajar.

Menurut Sudjana (2010:22) mengemukakan bahwa hasil belajar adalah kemampuan-kemampuan yang dimiliki peserta didik setelah ia menerima pengalaman belajarnya dan hasil belajar peserta didik pada hakekatnya adalah perubahan tingkah laku. Sedangkan menurut Hamalik (2005:30) mengemukakan bahwa hasil belajar adalah bila seseorang telah 
belajar akan terjadi perubahanperubahan tingkah laku pada orang tersebut, misalnya dari tidak tahu menjadi tahu dan tidak mengerti menjadi mengerti. Jadi dapat disimpulkan hasil belajar adalah kemampuan keterampilan, dan sikap yang diperoleh peserta didik setelah menerima perlakuan yang diberikan guru sehingga dapat berguna bagi kehidupannya sehari-hari.

Berdasarkan hasil penelitian dari hasil ulangan harian dan tugas harian yang dijelaskan oleh guru kelas adalah hasil belajar peserta didik rata-rata dibawah nilai KKM (Kriteria Ketunasan Minimal) bernilai 65. Jumlah peserta didik yang diamati adalah 18 orang peserta didik, dan terdapat sebanyak 11 $(61,11 \%)$ orang peserta didik masih dibawah standar KKM dan sebanyak 7 $(38,88 \%)$ orang peserta didik atau yang sudah mencapai KKM pada kelas VIII Madrasah Tsanawiyah Hidayatul Insan Palangka Raya. (sumber data: guru bidang studi IPS kelas VIII Madrasah Tsanawiyah Palangka Raya).

Rendahnya kemampuan peserta didik terhadap materi menjadi penyebab karena kurang termotivasinya peserta didik dalam proses pembelajaran sehingga dalam pembelajaran tidak efektif dan hasil belajar pun menjadi rendah. Hal ini disebabkan karena metode yang digunakan guru belum bervariasi dimana guru- dalam pembelajarannya menggunakan metode ceramah, dan berharap peserta di- dik mencatat dan mendengar penjelasan dari guru, sehingga membuat peserta didik cenderung pasif dan kurang aktif dalam proses pembelajaran.
Menurut Sapriya (2009:5) Istilah "Ilmu Pengetahuan Sosial", disingkat IPS merupakan nama mata pelajaran di tingkat sekolah dasar dan menengah atau nama program studi di perguruan tinggi yang identik dengan is- tilah "social studies" dalam kurikulum persekolahan di negara lain, khususnya di Negara-negara Barat seperti Australia dan Amerika Serikat. Nama "IPS" yang lebih dikenal social studiesdi Negara lain itu merupakan istilah kesepakatan dari para ahli atau pakar kita Indonesia dalam Seminar Nasional Tentang Civic Education tahun 1972 di Tawangmangu, Solo. IPS sebagai mata pelajaran di persekolahan, pertama kali digunakan dalam kurikulum 1975. Menurut Sapriya (2009:6) yang dimaksud Ilmu Pengetahuan Sosial adalah Ilmu Pengetahuan Sosial adalah mata pelajaran yang mempelajari kehidupan sosial yang didasarkan pada bahan kajian geografi, ekonomi, sejarah, antropologi, sosiologi dan tata negara. Khusus di Sekolah Lanjutan Tingkat Pertama program pengajaran IPS hanya mencakup bahan kajian geografi, ekonomi dan sejarah.

Suprijono

(2014:45-46) mengemukakan bahwa model pembelajaran merupakan landasan praktek pembelajaran hasil penurunan teori psikologi pendidikan dan teori belajar yang dirancang berdasarkan analisis terhadap implementasi kurikulum dan implementasinya pada tingkat operasional dikelas. Model pembelajaran dapat diartikan pula sebagai pola yang digunakan untuk penyusunan kurikulum, mengatur 
materi, dan memberi petunjuk kepada guru dikelas. model pembelajaran adalah suatu perencanaan atau pola yang dapat digunakan guru untuk mencapai tujuan belajar.

Berdasarkan hal tersebut, maka peneliti mencoba mengambil suatu tindakan yang kiranya dapat mengatasi masalah tersebut yaitu melalui model pembelajaran kooperatif dengan tipe Snowball Throwing (melempar bola salju). Menurut Huda (2013:126) mengemukakan bahwa model pembelajaran Snowball Throwing adalah pembelajaran di- mana peserta didik dibagi menjadi beberapa kelompok yang masing-masing kelompok diwakili seorang ketua kelompok untuk mendapat tugas dari guru. Masing-masing siswa membuat perta- nyaan di selembar kertas yang dibentuk seperti bola (kertas pertanyaan) lalu dilempar ke peserta didik lain. Peserta didik yang men- dapat lemparan kertas menjawab pertanyaan dalam kertas yang diperoleh.

$$
\text { Menurut Komalasari (2013:67) }
$$
mengemukakan bahwa model pembelajaran Snowball Throwing adalah Suatu model pembelajaran yang menggali potensi kepemimpinan peserta didik dalam kelompok dan keterampilan membuat-menjawab pertanyaan yang dipadukan melalui suatu permainan imajinatif membentuk dan melempar bola salju.

$\begin{array}{lcr}\text { Jadi } & \text { Snowball } & \text { Throwing } \\ \text { merupakan } & \text { salah satu } & \text { model } \\ \text { pembelajaran } & \text { kooperatif, } & \text { model } \\ \text { pembelajaran ini pada } & \text { dasarnya } \\ \text { digunakan untuk memberikan } & \text { konsep } \\ \text { pemahaman materi kepada } & \text { peserta }\end{array}$

didik serta dapat juga digunakan untuk mengetahui sejauh mana pengetahuan dan kemampuan peserta didik dalam memahami materi tersebut. Model Pembelajaran kooperatif tipe Snowball Throwing (melempar bola salju) merupakan pembelajaran yang menggali potensi kepemimpinan peserta didik dalam kelompok dan keterampilan membuat-menjawab pertanyaan yang dipadukan melalui permainan imajinatif membentuk dan melempar bola salju yang diawali dengan pembentukan kelompok dan diwakili ketua kelompok untuk mendapat tugas dari guru kemudian masing-masing peserta didik membuat pertanyaan yang dibentuk seperti bola salju (kertas pertanyaan) lalu dilempar ke peserta didik lain yang masingmasing peserta didik menjawab pertanyaan dari bola yang diperoleh.

$$
\text { Menurut Asrori }
$$

mengemukakan bahwa tujuan pembelajaran Snowball Throwing yaitu melatih murid untuk menmkmdengarkan pendapat orang lain, melatih kreatifitas dan imajinasi murid dalam membuat pertanyaan, serta memacu murid untuk bekerjasama, saling membantu, serta aktif dalam pembelajaran. Jadi tujuan model pembelajaran Snowball Throwing adalah melatih peserta didik dalam mengungkapkan pendapatnya serta melatih kreatifi- tas peserta didik dalam bekerjasama serta lebih aktif dalam pembelajaran.

Pada model ini masing-masing individu maupun kelompok akan lebih aktif untuk memecahkan masalah atau memahami konsep dan cenderung 
memberikan pengaruh positif terhadap peningkatkan hasil belajar peserta didik. Selain itu meningkatkan hasil belajar, keunggulan yang lainnya adalah membuat suasana di kelas menjadi menyenangkan sehingga peserta didik termotivasi untuk belajar.

Untuk itu, maka peneliti tertarik untuk melakukan penelitian yang berjudul "Upaya Meningkatkan Hasil Belajar IPS Ekonomi Dengan Menggunakan Model Pembelajaran Kooperatif Tipe Snowball ThrowingPada Kelas VIII Madrasah Tsanawiyah Hidayatul Insan Palangka Raya". Alasan peneliti memilih judul Model Pembelajaran Kooperatif tipe Snowball Throwing ini adalah karena model ini belum pernah digunakan dalam proses pembelajaran khususnya pada kelas VIII Usman bin Affan MTS Hidayatul Insan Palangka Raya pada mata pelajaran IPS Ekonomi. Selain itu juga dengan menerapkan Model Pembelajaran Kooperatif Tipe Snowball Throwing ini dapat membuat proses pembelajaran lebih bervariasi serta mempermudah peserta didik dalam memahami materi pembelajaran khususnya pada mata pelajaran IPS Ekonomi. Peneliti memandang bahwa dengan menerapkan Model Pembelajaran Kooperatif Tipe Snowball Throwing ini adalah suatu cara yang efektif untuk meningkatkan aktivitas serta hasil belajar peserta didik dalam proses pembelajaran di sekolah.

\section{METODE PENELITIAN}

Dalam proses penelitian ini peneliti menggunakan pendekatan penelitian tindakan kelas (PTK) yang bertujuan untuk mengetahui peningkatan aktivitas dan hasil belajar peserta didik.

Penelitian tindakan kelas berasal dari bahasa Inggris, yaitu Classroom Action Reseach yang artinya Action Reseach (penelitian dengan tindakan). Menurut Kunandar (2008:45) PTK terdiri dari tiga kata, yaitu penelitian, tindakan, dan kelas. Sedangkan menurut Kemmis dan Taggart (Abdulhak dan Suprayogi 2011:92) mengemukakan pula bahwa Penelitian Tindakan Kelas (PTK) adalah proses investigasi terkendali yang bersiklus dan bersifat reflektif dan mandiri yang dilakukan oleh guru atau tenaga kependidikan lainnya yang bertujuan untuk melakukan perbaikan-perbaikan terhadap sistem, cara kerja, proses, isi, kompetensi,atau situasi pembelajaran.

PTK dilakukan dengan tujuan memperbaiki mutu praktik pembelajaran dikelas secara lebih professional. Fokus PTK adalah pada peserta didik atau PBM yang terjadi di kelas. Tujuan utama PTK adalah untuk memecahkan permasalahan nyata yang terjadi di kelas. Penelitian ini dilaksanakan di MTs Hidayatul Insan Palangka Raya pada peserta didik kelas VIII ruang Usman bin Affan, dimana subjek penelitiannya adalah peserta didik kelas VIII ruang Usman bin Affan Palangka Raya.

\section{HASIL PEMBAHASAN}

Sesuai kegiatan yang telah dirancang pada BAB III, rancangan dalam penelitian tindakan kelas menggunakan prosedur penelitian yang dimulai dengan membuat rancangan 
tindakan yaitu (perencanaan), melaksanakan tindakan, observasi dan evaluasi dan refleksi, kemudian rancangan ini akan dilakukan pada setiap siklus.

Pada awal dan akhir pembelajaran peneliti nantinya akan memberikan test untuk mengetahui tingkat pemahaman peserta didik dalam memahami materi yang diajarkan dan dari hasil test ini yang akan menjadi perbandingan tingkat keberhasilan tindakan dengan menggunakn model pembelajaran kooperatif tipe Snowball Throwing.

1. Aktivitas Belajar Peserta Didik Ketika Menggunakan Model Pembelajaran Kooperatif Tipe Snowball Throwing

Dari hasil observasi aktivitas belajar peserta didik berdasarkan pengamatan antara dua orang observer yaitu guru mata pelajaran IPS Ekonomi dan teman sejawat setiap siklus dapat dilihat pada tabel berikut ini.

Tabel 13

Hasil Pengamatan Aktivitas peserta Didik Persiklus

\begin{tabular}{|r|c|}
\hline \multirow{2}{*}{ Siklus } & $\begin{array}{c}\text { Banyaknya Peserta } \\
\text { Didik Yang Memperoleh } \\
\text { Skor Di Atas 45 }\end{array}$ \\
\hline Siklu & 13 Orang Peserta \\
\hline Siklu & 18 Orang Peserta \\
\hline
\end{tabular}

Berdasarkan tabel di atas menunjukkan peningkatan aktivitas belajar peserta didik selama pembelajaran. Dimana pada siklus I aktivitas belajar ada 13 orang peserta didik yang memperoleh skor diatas 45 dengan kategori cukup, pada siklus II terjadi peningkatan peserta didik menjadi lebih aktif yaitu 15 orang peserta didik yang memperoleh skor di atas 45 dengan kategori baik.

Peningkatan Hasil Belajar Peserta Didik Setelah Menggunakan Model Pembelajaran Kooperatif Tipe Snowball Throwing

Peserta didik dari test awal sampai dengan siklus II setelah mengalami peningkatan, pada tes awal jumlah peserta didik dari 17 orang peserta didik yang tuntas ada 4 orang peserta didik atau $20 \%$ dan yang tidak tuntas ada 13 orang peserta didik (76,47\%), siklus I ada 13 orang peserta didik atau $(76,47)$ yang tuntas dan 4 orang peserta didik yang tidak tuntas atau (23,52\%), dan siklus II ada 15 orang peserta didik atau $(88,23 \%)$ yang tuntas dan 2 orang peserta didik yang tidak tuntas atau $(11,76 \%)$.

\section{KESIMPULAN}

Berdasarkan hasil pelaksanaan penelitian dan pembahasan, maka kesimpulan yang dapat di peroleh sebagai upaya meningkatkan hasil belajar IPS Ekonomi dengan menggunakan Model Pembelajaran Kooperatif Tipe Snowball Throwing pada peserta didik kelas VIII Usman bin Affan MTs Hidayatul Insan Palangka adalah sebagai berikut:

1. Aktivitas peserta didik dengan menggunakan model pembelajaran kooperatif tipe Snowball Throwing peserta didik lebih aktif dalam mengemukakan pendapat dan lebih berpartisipasi dalam proses pembelajaran IPS Ekonomi. Peserta didik aktif dalam berdiskusi dengan anggota kelompoknya, aktif dalam 
bertanya baik secara lisan maupun tertulis.

2. Ada peningktan hasil belajar IPS Ekonomi pada peserta didik dengan menggunakan model pembelajaran kooperatif tipe Snowball Throwing pada siklus I hasil pre test ada 4 peserta didik yang tuntas $23,52 \%$ dan hasil post test 13 peserta didik yang tuntas $76,47 \%$ dan pada siklus II hasil post test ada 15 peserta didik yang tuntas $88,23 \%$. Ini berarti dengan menggunakan model pembelajaran kooperatif tipe Snowball Throwing dapat meningkatkan hasil belajar peserta didik kelas VIII Usman bin Affan MTs Hidayatul Insan Palangka Raya.

\section{DAFTAR PUSTAKA}

Abdullhak, I \& suprayogi, U. 2011. Penelitian Tindakan Dalam Pendidikan Non Formal. Bandung: PT Raja Grafindo Persada.

Asrori Mohib. 2010. Penggunaan Model pembelajaran Snowball Throwing DalamMeningkatkan Keaktifan Belajar. Jakarta: Reneka Cipta.

Hamalik Omar. 2005. Proses Belajar Mengajar, Jakarta: Dian Rakyat.

Huda Miftahul. 2013. Model-model Pengajaran dan Pembelajaran Isu-Isu Metodis dan Paradigmatis. Yogyakarta: Pustaka Pelajar.

Komalasari Kokom. 2013. Pembelajaran Kontekstual Konsep dan Aplikasi. Bandung: Refika Aditama.

Kunandar. 2008. Langkah Mudah Penelitian Tindakan Kelas Sebagai Pengembangan Profesi Guru. Jakarta: PT RajaGrafindo Persada.

Sapriya, 2009. Pendidikan IPS Konsep dan Pembelajaran. Bandung: PT Remaja Rosdakarya.

Sudjana Nana. 2010. Penilaian Hasil Proses Belajar Mengajar. Bandung: PT Remaja Rosdakarya. Undang-Undang RI. 2003. Tentang Sistem Pendidikan Nasional. Bandung: Citra Umbara. 